\title{
Commentary: Implementing Pro-Poor Universal Health Coverage
}

\author{
Mihajlo Jakovljevic ${ }^{1,2 *}$ \\ ${ }^{1}$ The Faculty of Medical Sciences, University of Kragujevac, Kragujevac, Serbia, ${ }^{2}$ Hosei University Tokyo, Tokyo, Japan
}

Keywords: universal health coverage, low middle income countries, risk sharing, financial, BRICS, global health

\section{A commentary on}

Implementing Pro-Poor Universal Health Coverage

by Bump J, Cashin C, Chalkidou K, Evans D, González-Pier E, Guo Y, et al. Lancet Glob Health (2015) 4:e14-6. doi: 10.1016/S2214-109X(15)00274-0

Recently published extraordinary article entitled: "implementing pro-poor universal health coverage" depicts an issue of truly global outreach (1). Modern day health system establishments had their historical roots back in the early industrial era of late nineteenth century Europe (2). Risk sharing through introducing the first health insurance funds was initially targeted to protect industrial laborers as an important segment of the society of the time (3). Health coverage of citizens beneath poverty line therefore began to slowly expand to the other vulnerable groups. During the first half of twentieth century, such practice spreads to North America (4) and Japan (5). It is less known that

OPEN ACCESS

Edited by:

Sandra C. Buttigieg,

University of Malta, Malta

Reviewed by:

Krzysztof Kaczmarek,

Medical University of Silesia, Poland

Kyriakos Souliotis,

University of Peloponnese, Greece

*Correspondence:

Mihajlo Jakovljevic sidartagothama@gmail.com, jakovljevicm@medf.kg.ac.rs

Specialty section: This article was submitted to Health Economics, a section of the journal Frontiers in Public Health

Received: 16 July 2016 Accepted: 17 August 2016 Published: 29 August 2016

Citation: Jakovljevic M (2016) Commentary: Implementing Pro-Poor Universal Health Coverage.

Front. Public Health 4:186. doi: 10.3389/fpubh.2016.00186 the first nationwide success in achieving universal health coverage (UHC) is attributable to the early Soviet Union back in 1930s and its famous Semashko system (6). Disintegration of colonial system worldwide after the end of WWII and rise of the non-aligned movement gave significant impetus to the health system developments among the Third World nations (7). After the end of Cold War Era, accelerated pace of globalization saw the uneven growth of welfare in these countries (8). Although attractive as a policy goal, health coverage for massive rural populations remained a distant dream for many world regions (9).

The aforementioned paper by Bump et al. pointed out to the core global UHC developments in a comprehensive manner. Their call to national governments to commit to the established milestones of UHC evolution is clear and might indeed serve the purpose. Nevertheless, few crucial facts were omitted, which might significantly narrow the horizon of perception on global evolution of UHC with regard to the role of BRICS nations (10).

Due to overall increase in welfare, UHC for the poor rapidly expanded around the world (11). Therefore, it seems that we might be deceived by perception that all of these world regions contributed evenly or at least to the comparable extent (12). The reality is rather different: there is a very narrow circle of top emerging economies to which we own most of this progress. Lion share of the growth in UHC, the world owns to the BRICS nations (13). Accounting for roughly two-fifths of world's population, over the past two decades these national governments lifted from poverty hundreds of millions of the world's poorest citizens (14). Quite efficient government policies dedicated to reducing poverty took place in these economies since late 1990s with few notable examples led by Chinese overachievement (15-17). Such an increase in social welfare of poorest citizens was attributable to industrial enterprise and direct foreign investment $(18,19)$. Their health reforms were bold and successful to the large extent leading to the notable gains toward achieving UHC (20). Distinctive role of these economies in global health arena led WHO Bulletin to establish a specialty issue committed to BRICS back in 2014 (21). Some of the exposed weaknesses alongside this ambitious process were India's inability to expand health expenditure in terms of GDP percentage (22). Socioeconomic inequalities in health care expanded in some members of the group driven by 
exploding prevalence of prosperity diseases (23). Despite the fact of these obstacles accelerated expansion of UHC remains clearly visible in Russia, Brazil, India, and China (24). One of the surprising developments is the strong and continuing upward trend of their national abilities to increase investment in health care and expand insurance coverage of the population below poverty line (25). Long-term commitment of BRICS governments ultimately resulted in significantly improved health outcomes, including

\section{REFERENCES}

1. Bump J, Cashin C, Chalkidou K, Evans D, González-Pier E, Guo Y, et al. Implementing pro-poor universal health coverage. Lancet Glob Health (2015) 4:e14-6. doi:10.1016/S2214-109X(15)00274-0

2. Rosen G. From Medical Police to Social Medicine: Essays on the History of Health Care. New York: Science History Publications, Neale Watson Academic Publications, Inc. (1974)

3. Sigerist HE. From Bismarck to Beveridge: developments and trends in social security legislation. Bull Hist Med (1943) 13:365-88.

4. Getzen TE. Health care is an individual necessity and a national luxury: applying multilevel decision models to the analysis of health care expenditures. J Health Econ (2000) 19(2):259-70. doi:10.1016/S0167-6296(99)00032-6

5. Ogura S, Jakovljevic M. Health financing constrained by population aging an opportunity to learn from Japanese experience. Ser J Exp Clin Res (2014) 15(4):175-81. doi:10.2478/SJECR

6. Semashko NA. Health Protection in the USSR. London: Victor Gollancz (1934). p. 39-40.

7. Morphet S. Multilateralism and the non-aligned movement: what is the global South doing and where is it going? Glob Govern (2004) 10(4):517-37.

8. Jakovljevic MB. Resource allocation strategies in Southeastern European health policy. Eur J Health Econ (2013) 14(2):153-9. doi:10.1007/s10198-012-0439-y

9. Jakovljevic M, Groot W, Souliotis K. Health care financing and affordability in the emerging global markets. Front Public Health (2016) 4:2. doi:10.3389/ fpubh.2016.00002

10. O’Neill J. Building Better Global Economic BRICs. Global Economics Paper No: 66 ()2001. Goldman, Sachs \& Co (2001).

11. Jakovljevic M, Getzen T. Growth of global health spending share in low and middle income countries. Front Pharmacol (2016) 2016(7):21. doi:10.3389/ fphar.2016.00021

12. McIntyre D, Thiede M, Dahlgren G, Whitehead M. What are the economic consequences for households of illness and of paying for health care in low-and middle-income country contexts? Soc Sci Med (2006) 62(4):858-65. doi:10.1016/j.socscimed.2005.07.001

13. Marten R, McIntyre D, Travassos C, Shishkin S, Longde W, Reddy S, et al. An assessment of progress towards universal health coverage in Brazil, Russia, India, China, and South Africa (BRICS). Lancet (2014) 384(9960):2164-71. doi:10.1016/S0140-6736(14)60075-1

14. Jakovljevic M. The key role of leading emerging BRIC markets for the future of global health care, SJECR, UDK: 614.2(100). Ser J Exp Clin Res (2014) 15(3):139-43. doi:10.5937/sjecr1403139J

15. Hemson D, Owusu-Ampomah K. A Better Life for All? Service Delivery and Poverty Alleviation. South Africa: State of the Nation (2004). p. 511-36.

16. Lemus E, Abreu A. The persistent poverty level in the United States vs. the BRICs emerging economies market. J Asia Pac Stud (2015) 4(2):169-76. nationwide longevity (26). A global landscape of UHC evolution implies that orchestrated international efforts should regard these nations as one of the pillars of any responsible policy aimed to protect the world's poor from health-related risks.

\section{AUTHOR CONTRIBUTIONS}

MJ has designed drafted and finalized the manuscript.

17. Kickbusch I. BRICS? Contributions to the global health agenda. Bull World Health Organ (2014) 92(6):463-4. doi:10.2471/BLT.13.127944

18. Yu M. Industrial Structural Upgrading and Poverty Reduction in China, the Untold Story: Structural Change for Poverty Reduction: The Case of the BRICS. Beijing: Peking University (2012).

19. United Nations Industrial Development Organization. Structural Change, Poverty Reduction and Industrial Policy in the BRICS. Vienna: United Nations University (2012). Available from: http://www19.iadb.org/intal/intalcdi/ PE/2013/10846.pdf

20. Rao KD, Petrosyan V, Araujo EC, McIntyre D. Progress towards universal health coverage in BRICS: translating economic growth into better health. Bull World Health Organ (2014) 92(6):429-35. doi:10.2471/ BLT.13.127951

21. McKee M, Marten R, Balabanova D, Watt N, Huang Y, Finch AP, et al. BRICS? Role in global health and the promotion of universal health coverage: the debate continues. Bull World Health Organ (2014) 92(6):452-3. doi:10.2471/ BLT.13.132563

22. Barik D, Thorat A. Issues of unequal access to public health in India. Front Public Health (2015) 2015(3):245. doi:10.3389/fpubh.2015.00245

23. Jakovljevic M, Milovanovic O. Growing burden of non-communicable diseases in the emerging health markets: the case of BRICS; Research topic: health care financing and affordability in the emerging global markets. Front Public Health (2015) 3:65. doi:10.3389/fpubh.2015.00065

24. Jakovljevic MB. BRIC's growing share of global health spending and their diverging pathways. Front Public Health (2015) 3:135. doi:10.3389/ fpubh.2015.00135

25. Jakovljevic MM. Comparison of historical medical spending patterns among the BRICS and G7. J Med Econ (2016) 19(1):70-6. doi:10.3111/13696998.20 15.1093493

26. Jakovljevic M, Vukovic M, Fontanesi J. Life expectancy and health expenditure evolution in Eastern Europe - DiD and DEA analysis. Expert Rev Pharmacoecon Outcomes Res (2015) 17:1-10. doi:10.1586/14737167. 2016.1125293

Conflict of Interest Statement: The author declares that the research was conducted in the absence of any commercial or financial relationships that could be construed as a potential conflict of interest.

Copyright (C) 2016 Jakovljevic. This is an open-access article distributed under the terms of the Creative Commons Attribution License (CC BY). The use, distribution or reproduction in other forums is permitted, provided the original author(s) or licensor are credited and that the original publication in this journal is cited, in accordance with accepted academic practice. No use, distribution or reproduction is permitted which does not comply with these terms. 